\title{
Studi Evaluatif Penyelenggara Pendidikan Agama Hindu Terhadap Pencapaian Pendidikan Agama Hindu Sekolah Menengah Atas Dwijendra Di Denpasar
}

\author{
I Nyoman Subagia*, I Made Suta \\ Institut Hindu Dharma Negeri Denpasar \\ *nyomansubagia1182@gmail.com
}

DOI : $10.37329 /$ cetta.v3i1.407

\begin{tabular}{l} 
Keywords: \\
\hline Evaluative Study, \\
Organizing Hindu \\
Religious \\
Education. \\
\hline
\end{tabular}

\begin{abstract}
This research has several underlying factors, including; (1) to date there has been no independent or related evaluation carried out so that Hindu education in the Dwijendra school in Denpasar is unknown, (2) Interesting phenomena here are found in small islands in Indonesia, such as in Bali where the majority of the population is Hindu, and Hindu people prefer schools in non Hindu-based schools, it is suspected, school-based management in Dwijendra High School in Denpasar has not been maximally achieved in accordance with the goals of the organization. The main objective of this study is to determine the effectiveness of independent variables or predictors consisting of context variables (X1), input (X2), process (X3), and product (X4) while competency achievement is treated as a dependent variable or criterion with a symbol $(Y)$. The analytical method in accordance with the objectives of the research design used is simple or multiple regression because it consists of three independent variables and one dependent variable. The results of the study are as follows: (1) there is a relationship between context and the achievement of Hindu religious education competencies with a value of 0.229 using a significance level of $0.05(0.000<0.05)$, then the alternative hypothesis is accepted, (2) there is a relationship between inputs with the achievement of Hindu religious education competence with a value of 0.180 using a significance level of $0.05(0.000<0.05)$, then the null hypothesis is accepted, (3) there is a relationship between the process of achieving Hindu religious education competence with a value of 0.957 using the level significance of $0.05(0,000<0.05)$, then the null hypothesis is accepted, (4) there is a relationship between the product and the achievement of Hindu religious education competence with a value of 0.339 using a significance level of 0.05 $(0,000<0.05)$, then the hypothesis zero accepted, (5) there is a relationship between the context, input, process, and product with the achievement of Hindu religious education competence with a value of 0.276 , de using a significance level of $0.05(0,000<0.05)$.
\end{abstract}




\begin{tabular}{l}
\hline Kata Kunci: \\
\hline Studi Evaluatif, \\
Penyelenggaraan \\
Pendidikan \\
Agama Hindu. \\
\hline
\end{tabular}

Agama Hindu.
Abstrak (1) sampai saat ini belum ada evaluasi yang dilakukan independen atau pihak terkait sehingga belum diketahui penyelenggaraan pendidikan agama Hindu di sekolah Dwijendra di Denpasar, (2) Fenomena menarik disini dijumpai pulau kecil di Indonesia, seperti daerah Bali yang mayoritas penduduknya beragama Hindu, dan orang beragama Hindu lebih memilih sekolah di sekolah-sekolah berbasi non Hindu, hal ini diduga, menejemen berbasis sekolah di Sekolah Menengah Atas Dwijendra di Denpasar belum maksimal tercapai sesuai dengan tujuan organisasi. Tujuan utama penelitian ini adalah untuk mengetahui efektivitas antara variabel bebas atau prediktor yang terdiri atas variabel konteks $\left(X_{1}\right)$, input $\left(X_{2}\right)$, proses $\left(X_{3}\right)$, dan produk $\left(X_{4}\right)$ sedangkan pencapaian kompetensi diperlakukan sebagai variabel terikat atau kriterium dengan lambang (Y). Metode analisis yang sesuai dengan tujuan rancangan penelitian yang digunakan adalah regresi sederhana maupun ganda karena terdiri atas tiga variabel bebas dan satu variabel terikat. Hasil penelitian adalah sebagai berikut : (1) terdapat hubungan antara kontek dengan pencapaian kompetensi pendidikan agama Hindu dengan nilai sebesar 0,229 dengan menggunakan taraf signifikansi $0,05(0,000<0,05)$, maka hipotesis alternative diterima, (2) terdapat hubungan antara input dengan pencapaian kompetensi pendidikan agama Hindu dengan nilai sebesar 0,180 dengan menggunakan taraf signifikansi $0,05(0,000<0,05)$, maka hipotesis nol diterima, (3) terdapat hubungan antara proses dengan pencapaian kompetensi pendidikan agama Hindu dengan nilai sebesar 0,957 dengan menggunakan taraf signifikansi 0,05 (0,000 < 0,05), maka hipotesis nol diterima, (4) terdapat hubungan antara produk dengan pencapaian kompetensi pendidikan agama Hindu dengan nilai 0,339 dengan menggunakan taraf signifikansi 0,05 $(0,000<0,05)$, maka hipotesis nol diterima, (5) terdapat hubungan antara kontek, input, proses, dan produk dengan pencapaian kompetensi pendidikan agama Hindu dengan nilai sebesar 0,276 , dengan menggunakan taraf signifikansi $0,05(0,000<0,05)$.

\section{Pendahuluan}

Peraturan Pemerintah Nomor 19 Tahun 2005 tentang Standar Nasional Pendidikan salah satu standar yang harus dikembangkan adalah standar proses adalah standar nasional pendidikan yang berkaitan dengan pelaksanaan pembelajaraan pada suatu pendidikan untuk mencapai kompetensi lulusan. Standar proses berisi kreteria minimal proses pembelajaran pada suatu pendidikan dasar dan 
menengah di seluruh wilayah hukum Negara Kesatuan Republik Indonesia. Standar proses meliputi perencanaan proses pembelajaran, pelaksanaan proses pembelajaran, penilaian hasil pembelajaran, dan pengawasan proses pembelajaran untuk terlaksananya proses pembelajaran yang efektif dan efisien.

Otonomi dalam mengelola pembelajaran merupakan potensi bagi sekolah untuk meningkatkan kinerja guru. Sekolah sebagai pendidikan formal merupakan lembaga yang memiliki kewajiban untuk membentuk peserta didik menjadi pribadi yang berkarakter luhur (Sudarsana, 2017). Oleh karena itu, guru juga berperan sebagai seorang manajer yang mengelola pembelajaran dengan baik untuk mencapai tujuan pembelajaran. Tolok ukur hasil pendidikan dapat diketahui dengan adanya evaluasi (Arikunto, 2019). Dalam proses manajemen (pengelolaan), guru pendidikan agama Hindu terlibat fungsi-fungsi pokok yang ditampilkan oleh seorang manajer, yaitu perencanaan (planning), pengorganisasian (organizing), pelaksanaan (actuating), kepemimpinan (leading), dan evaluasi (controling) dalam pembelajaran. Hal ini sebagaimana definisi manajemen sebagai berikut: "Management is distinct process consisting of planning (manajemen adalah proses yang berbeda yang terdiri dari perencanaan)" dan kebiasaan yang dilakukan secara sadar, terus menerus dalam bentuk organisasi. Pendidikan berkembang disertai dengan merosotnya ahlak dan moral siswa-siswi (Sudarsana, 2017).

Terkait hal ini ada beberapa hal yang mendasari penelitian ini yaitu: (1) sampai saat ini belum ada evaluasi yang dilakukan independen atau pihak terkait sehingga belum diketahui penyelenggaraan pendidikan agama Hindu di sekolah Dwijendra di Denpasar, (2) Fenomena menarik disini dijumpai pulau kecil di Indonesia, seperti daerah Bali yang mayoritas penduduknya beragama Hindu dan orang beragama Hindu lebih memilih sekolah di sekolah-sekolah Dwijendra, hal ini terkait dengan menejemen berbasis sekolah di Sekolah Menengah Atas (SMA) Dwijendra di Denpasar sudah tercapai sesuai dengan tujuan organisasi. Manajemen berbasis sekolah merupakan proses dari pelaksanaan fungsi-fungsi komponen yang terdapat dalam proses pembelajaran. Adapun yang termasuk kedalam komponen-komponen pembelajaran tersebut adalah: (1) menajemen kurikulum, (2) menajemen kesiswaan, (3) menajemen tenaga pendidik, (4) menajemen sarana dan prasarana, (5) menajemen keuangan, dan (6) menajemen hubungan masyarakat (Suderajat, 2005:23). 
Berdasarkan uraian di atas dalam opreasionalnya semua komponen yang terdapat dalam menajemen pendidikan juga dilaksanakan secara utuh dan berkelanjutan oleh peserta didik dan tenaga pendidik agama Hindu di Sekolah Menengah Atas Dwijendra di Denpasar, (3) perlu diketahui penyelenggaraan pendidikan agama Hindu di Sekolah Menengah Atas Dwijendra di Denpasar. Penyelenggaraan pendidikan agama Hindu terhadap pencapaian kompetensi pendidikan agama Hindu di sekolah menengah atas Dwijendra di Denpasar, diharapkan dapat menjadi contoh dan pengendali mutu serta menjadi acuan atau rujukan bagi penyelenggaraan pendidikan agama Hindu di sekolah menengah atas Dwijendra di Provinsi Bali. Berdasarkan uraian diatas, yang menjadi permasalahan disini adalah seberapa efektivitas penyelenggaraan pendidikan agama Hindu terhadap pencapaian kompetensi pendidikan agama Hindu di Sekolah Menengah Atas Dwijendra di Denpasar.

\section{Metode}

Penelitian ini mempergunakan pendekatan evaluatif, dengan menganalisis peran masing-masing faktor sesuai dengan model CIPP (Consept, input, procces dan product). Evaluasi pendidikan adalah kegiatan pengendalian, penjaminan dan penetapan mutu pendidikan terhadap berbagai komponen pendidikan pada setiap jalur, jenjang, dan jenis pendidikan sebagai benntk pertanggungjawaban penyelenggaraan pendidikan (Indonesia, 2003).

Secara kuantitatif proses evaluasi dilakukan dengan menekankan pada aspek obyektivitas, realibilitas dan validitas pengukuran yang difokuskan pada data dalam bentuk angka-angka. Untuk itu pengumpulan data dilakukan dengan instrumen berbentuk kuesioner dengan model skala likert dan lembar observasi dengan cek lis. Metode analisis yang sesuai dengan tujuan rancangan penelitian yang digunakan adalah regresi sederhana maupun ganda karena terdiri atas tiga variabel bebas dan satu variabel terikat (Kerlinger, 1985 :116).

\section{Hasil dan Pembahasan}

Pencarian tingkat kategori variabel pencapaian kompetensi pendidikan agama Hindu di Sekolah Menengah Atas Dwijendra Denpasar dilakukan dengan terlebih dahulu menghitung mean ideal (Mi) dan standar deviasi ideal (Sdi). Mi $=1 / 2 \times$ (skor 
maksimal ideal + skor minimal ideal $)=1 / 2 \times(280+70)=175$. SDi $=1 / 6 \times($ skor maksimal ideal - skor minimal ideal $)=1 / 6 \times(280-70)=58$. Berdasarkan hasil perhitungan Mi dan SDi, diperoleh $\mathrm{Mi}+1,5 \mathrm{SDi}=175+1,5(58)=262 ; \mathrm{Mi}+0,5 \mathrm{SDi}=$ $175+0,5(58)=204 ; \mathrm{Mi}-0,5 \mathrm{SDi}=175-0,5(58)=146 ;$ dan $\mathrm{Mi}-1,5 \mathrm{SDi}=175-1,5(58)=$ 88. Berdasarkan hasil perhitungan tersebut selanjutnya disusun klasifikasi tingkat kategori variabel pencapaian kompetensi pendidikan agama Hindu di Sekolah Menengah Atas Dwijendra Denpasar seperti berikut.

Tabel 1 Tingkat Kategori Variabel Pencapaian Kompetensi Pendidikan Agama Hindu di Sekolah Menengah Atas Dwijendra Denpasar.

\begin{tabular}{|c|c|c|c|l|}
\hline No & Kelas Interval & Frekuensi & Persentase & Kategori \\
\hline 1. & $262-280$ & 31 & 17 & Sangat baik \\
\hline 2. & $204-261$ & 104 & 58 & Baik \\
\hline 3. & $146-203$ & 45 & 25 & Sedang \\
\hline 4. & $88-145$ & - & - & Kurang \\
\hline 5 & $70-86$ & - & - & Sangat Kurang \\
\hline & & 180 & 100,0 & \\
\hline
\end{tabular}

Berdasarkan hasil perhitungan pada tabel diatas dapat disimpulkan bahwa variabel pencapaian kompetensi pendidikan agama Hindu di sekolah menengah Atas Dwijendra Denpasar cenderung berada pada kategori baik sebanyak 104 responden atau sebesar $58 \%$, berada pada kategori sangat baik sebanyak 31 responden atau $17 \%$ selebihnya berada pada kategori sedang sebanyak 25 responden atau $45 \%$. Pencarian tingkat kategori variabel kontek di sekolah menengah pertama Swasta di Denpasar dilakukan dengan terlebih dahulu menghitung mean ideal (Mi) dan standar deviasi ideal (Sdi). Mi $=1 / 2 \times($ skor maksimal ideal + skor minimal ideal $)=1 / 2 \times(120+30)=75$. $\mathrm{SDi}=1 / 6 \times($ skor maksimal ideal - skor minimal ideal $)=1 / 6 \times(120-30)=15$. Berdasarkan hasil perhitungan Mi dan SDi, diperoleh Mi + 1,5 SDi = 75 + 1,5(15) = 98; $\mathrm{Mi}+0,5 \mathrm{SDi}=75+0,5(15)=83 ; \mathrm{Mi}-0,5 \mathrm{SDi}=75-0,5(15)=68 ;$ dan $\mathrm{Mi}-1,5 \mathrm{SDi}=75-$ $1,5(15)=53$. Berdasarkan hasil perhitungan tersebut selanjutnya disusun klasifikasi tingkat kategori variabel kontek di Sekolah Menengah Atas Dwijendra Denpasar seperti berikut. 
Tabel 2 Klasifikasi Tingkat Kategori Variabel Kontek

di Sekolah Menengah Atas Dwijendra Denpasar.

\begin{tabular}{|c|c|c|c|l|}
\hline No. & Kelas Interval & Frekuensi & Persentase & Kategori \\
\hline 1. & $98-120$ & 52 & 29 & Sangat baik \\
\hline 2. & $83-97$ & 120 & 66,5 & Baik \\
\hline 3. & $68-82$ & 8 & 4,5 & Sedang \\
\hline 4. & $53-67$ & - & - & Kurang \\
\hline 5 & $30-52$ & - & - & Sangat Kurang \\
\hline & & 180 & 100,0 & \\
\hline
\end{tabular}

Berdasarkan hasil perhitungan pada Tabel 2 dapat disimpulkan bahwa variabel kontek di Sekolah Menengah Atas Dwijendra Denpasar cenderung berada pada kategori baik sebanyak 120 responden atau sebesar 66,5\%, selebihnya berada pada kategori sangat baik sebanyak 52 responden atau 29\%, dan berada pada kategori sedang sebanyak 8 responden atau 4,5\%. Pencarian tingkat kategori variabel input di Sekolah Menengah Atas Dwijendra Denpasar dilakukan dengan terlebih dahulu menghitung mean ideal (Mi) dan standar deviasi ideal (Sdi). Mi $=1 / 2 \times$ (skor maksimal ideal + skor minimal ideal $)=1 / 2 \times(120+30)=75 . \mathrm{SDi}=1 / 6 \times($ skor maksimal ideal skor minimal ideal $)=1 / 6 \times(120-30)=15$. Berdasarkan hasil perhitungan Mi dan SDi, diperoleh $\mathrm{Mi}+1,5 \mathrm{SDi}=75+1,5(15)=98 ; \mathrm{Mi}+0,5 \mathrm{SDi}=75+0,5(15)=83 ; \mathrm{Mi}-0,5 \mathrm{SDi}$ $=75-0,5(15)=68$; dan $\mathrm{Mi}-1,5 \mathrm{SDi}=75-1,5(15)=53$. Berdasarkan hasil perhitungan tersebut selanjutnya disusun klasifikasi tingkat kategori variabel input di Sekolah Menengah Atas Dwijendra Denpasar seperti berikut.

Tabel 3 Klasifikasi Tingkat Kategori Variabel Input

di Sekolah Menengah Atas Dwijendra Denpasar.

\begin{tabular}{|c|c|c|c|l|}
\hline No. & Kelas Interval & Frekuensi & Persentase & Kategori \\
\hline 1. & $98-120$ & 27 & 15,1 & Sangat baik \\
\hline 2. & $83-97$ & 145 & 80,5 & Baik \\
\hline 3. & $68-82$ & 8 & 4,3 & Sedang \\
\hline 4. & $53-67$ & - & - & Kurang \\
\hline 5 & $30-52$ & - & - & Sangat Kurang \\
\hline & & 180 & 100,0 & \\
\hline
\end{tabular}

Berdasarkan hasil perhitungan pada Tabel 3 dapat disimpulkan bahwa variabel input di Sekolah Menengah Atas Dwijendra Denpasar cenderung berada pada 
kategori baik sebanyak 145 responden atau sebesar 80,5\%, berada pada kategori sangat baik sebanyak 27 responden atau 15,1\% sedangkan selebihnya berada pada kategori sedang sebanyak 8 responden atau 4,3\%. Pencarian tingkat kategori variabel proses di Sekolah Menengah Atas Dwijendra Denpasar dilakukan dengan terlebih dahulu menghitung mean ideal (Mi) dan standar deviasi ideal (Sdi). Mi = 1/2 x (skor maksimal ideal + skor minimal ideal $)=1 / 2 \times(120+30)=75 . \mathrm{SDi}=1 / 6 \times($ skor maksimal ideal skor minimal ideal $)=1 / 6 \times(120-30)=15$. Berdasarkan hasil perhitungan Mi dan SDi, diperoleh $\mathrm{Mi}+1,5 \mathrm{SDi}=75+1,5(15)=98 ; \mathrm{Mi}+0,5 \mathrm{SDi}=75+0,5(15)=83 ; \mathrm{Mi}-0,5 \mathrm{SDi}$ $=75-0,5(15)=68$; dan $\mathrm{Mi}-1,5 \mathrm{SDi}=75-1,5(15)=53$. Berdasarkan hasil perhitungan tersebut selanjutnya disusun klasifikasi tingkat kategori variabel proses di Sekolah Menengah Atas Dwijendra Denpasar.

Tabel 4 Klasifikasi Tingkat Kategori Variabel Proses di Sekolah Menengah Atas Dwijendra Denpasar.

\begin{tabular}{|c|c|c|c|l|}
\hline No. & Kelas Interval & Frekuensi & Persentase & Kategori \\
\hline 1. & $98-120$ & 77 & 41,6 & Sangat baik \\
\hline 2. & $83-97$ & 103 & 58,3 & Baik \\
\hline 3. & $68-82$ & - & - & Sedang \\
\hline 4. & $53-67$ & - & - & Kurang \\
\hline 5 & $30-52$ & - & - & Sangat Kurang \\
\hline & & 180 & 100,0 & \\
\hline
\end{tabular}

Berdasarkan hasil perhitungan pada Tabel 4. dapat disimpulkan bahwa variabel proses di Sekolah Menengah Atas Dwijendra Denpasar cenderung berada pada kategori baik sebanyak 103 responden atau sebesar 58,3\%, dan selebihnya berada pada kategori sangat baik sebanyak 77 responden atau 41,6\%. Pencarian tingkat kategori variabel produk di sekolah menengah Atas Dwijendra Denpasar dilakukan dengan terlebih dahulu menghitung mean ideal (Mi) dan standar deviasi ideal (Sdi). Mi $=1 / 2 \times($ skor maksimal ideal + skor minimal ideal $)=1 / 2 \times(120+30)=75$. SDi $=1 / 6 x$ $($ skor maksimal ideal - skor minimal ideal $)=1 / 6 \times(120-30)=15$. Berdasarkan hasil perhitungan Mi dan SDi, diperoleh $\mathrm{Mi}+1,5 \mathrm{SDi}=75+1,5(15)=98 ; \mathrm{Mi}+0,5 \mathrm{SDi}=75+$ $0,5(15)=83 ; \mathrm{Mi}-0,5 \mathrm{SDi}=75-0,5(15)=68 ;$ dan $\mathrm{Mi}-1,5 \mathrm{SDi}=75-1,5(15)=53$. Berdasarkan hasil perhitungan tersebut selanjutnya disusun klasifikasi tingkat kategori variabel produk di sekolah menengah Atas Dwijendra Denpasar. 
Tabel 5 Klasifikasi Tingkat Kategori Variabel Produk

di Sekolah Menengah Atas Dwijendra Denpasar.

\begin{tabular}{|c|c|c|c|l|}
\hline No. & Kelas Interval & Frekuensi & Persentase & Kategori \\
\hline 1. & $98-120$ & 72 & 40 & Sangat baik \\
\hline 2. & $83-97$ & 107 & 59,4 & Baik \\
\hline 3. & $68-82$ & 1 & 0,6 & Sedang \\
\hline 4. & $53-67$ & - & - & Kurang \\
\hline 5 & $30-52$ & - & - & Sangat Kurang \\
\hline & & 180 & 100,0 & \\
\hline
\end{tabular}

Berdasarkan hasil perhitungan pada table diatas dapat disimpulkan bahwa variabel produk di sekolah menengah Atas Dwijendra Denpasar cenderung berada pada kategori baik sebanyak 107 responden atau sebesar 59,4\%, selebihnya berada pada kategori sangat baik sebanyak 72 responden atau $40 \%$, dan pada kategori sedang sebanyak 1 responden atau $0,6 \%$.

\section{Hubungan Antara Kontek dengan Pencapaian Kompetensi Pendidikan Agama Hindu di Sekolah Menengah Atas Dwijendra Denpasar}

Berdasarkan hasil analisis korelasi sederhana didapat nilai korelasi $\left(\mathrm{r}_{\mathrm{x} 1 \mathrm{y}}\right)$ sebesar 0,229 dan signifikansi sebesar 0,000. Dengan menggunakan taraf signifikansi 0,05 $(0,000<0,05)$, maka hipotesis alternative yang berbunyi terdapat hubungan/efektivitas antara kontek dengan pencapaian kompetensi pendidikan agama Hindu di Sekolah Menangah Atas Dwijendra Denpasar diterima. Salah satu tupoksi guru yang sangat penting adalah keterampilan melakukan penilaian hasil belajar peserta didik (Kunandar, 2015). Dengan demikian, dapat disimpulkan bahwa terdapat hubungan antara kontek dengan pencapaian kompetensi pendidikan agama Hindu di Sekolah Menangah Atas Dwijendra Denpasar. Efikasi pengajaran merupakan variabel penting dalam kajian pendidikan guru kerana pengaruhnya (Khairani, 2016).

\section{Hubungan Antara Input dengan Pencapaian Kompetensi Pendidikan Agama Hindu di Sekolah Menengah Atas Dwijendra Denpasar}

Hipotesis nihil yang diajukan berbunyi terdapat hubungan antara input dengan pencapaian kompetensi pendidikan agama Hindu di sekolah menengah Atas Dwijendra Denpasar. Untuk menentukan tingkat ketercapaian pembelajaran yang 
telah dicapai oleh peserta didik, maka guru harus melakukan evaluasi (Darojat, 2015). Untuk menguji hipotesis ini, dilakukan dengan teknik korelasi sederhana dengan bantuan program SPSS for windows versi 20.0. Berdasarkan hasil analisis korelasi sederhana didapat nilai korelasi $\left(\mathrm{r}_{\mathrm{x} 2 \mathrm{y}}\right)$ sebesar 0,180 dan signifikansi sebesar 0,004. Dengan menggunakan taraf signifikansi 0,05 $(0,000<0,05)$, maka hipotesis nol yang berbunyi terdapat hubungan antara input dengan pencapaian kompetensi pendidikan agama Hindu di Denpasar diterima. Dengan demikian, dapat disimpulkan bahwa terdapat hubungan antara input dengan pencapaian kompetensi pendidikan agama Hindu di Sekolah Menengah Atas Dwijendra di Denpasar.

\section{Hubungan Antara Proses dengan Pencapaian Kompetensi Pendidikan Agama Hindu di Sekolah Menengah Atas Dwijendra Denpasar}

Hipotesis nol yang diajukan berbunyi terdapat hubungan antara proses dengan pencapaian kompetensi pendidikan agama Hindu di Sekolah Menengah Atas Dwijendra Denpasar. Untuk menguji hipotesis ini, dilakukan dengan teknik korelasi sederhana dengan bantuan program SPSS for windows versi 20.0. Berdasarkan hasil analisis korelasi sederhana didapat nilai korelasi $\left(\mathrm{r}_{\mathrm{x} 3 \mathrm{y}}\right)$ sebesar 0,957 dan signifikansi sebesar 0,000. Dengan menggunakan taraf signifikansi $0,05(0,000<0,05)$, maka hipotesis nol yang berbunyi terdapat hubungan antara proses dengan pencapaian kompetensi pendidikan agama Hindu di Sekolah Menengah Atas Dwijendra Denpasar diterima. Pada fase proses, orangtua bekerjasama dengan para guru dan kepala sekolah untuk memberikan penguatan kepada peserta didik dalam menerapkan nilainilai kepempinan yang baik melalui budaya organisasi di sekolah (Megawanti, 2012). Dengan demikian, dapat disimpulkan bahwa terdapat hubungan antara proses dengan pencapaian kompetensi pendidikan agama Hindu di Sekolah Menengah Atas Dwijendra Denpasar.

\section{Hubungan Antara Produk Dengan Pencapaian Kompetensi Pendidikan Agama Hindu di Sekolah Menengah Atas Dwijendra Denpasar}

Hipotesis nol yang diajukan berbunyi terdapat hubungan antara produk dengan pencapaian kompetensi pendidikan agama Hindu di Sekolah Menengah Atas Dwijendra Denpasar. Untuk menguji hipotesis ini, dilakukan dengan teknik korelasi sederhana dengan bantuan program SPSS for windows versi 20.0. Berdasarkan hasil 
analisis korelasi sederhana didapat nilai korelasi $\left(\mathrm{r}_{\mathrm{x} 4 \mathrm{y}}\right)$ sebesar 0,339 dan signifikansi sebesar 0,000. Dengan menggunakan taraf signifikansi $0,05(0,000<0,05)$, maka hipotesis nol yang berbunyi terdapat hubungan antara produk dengan pencapaian kompetensi pendidikan agama Hindu di Sekolah Menengah Atas Dwijendra Denpasar diterima. Dengan demikian, dapat disimpulkan bahwa terdapat hubungan antara produk dengan kompetensi pendidikan agama Hindu di Sekolah Menengah Atas Dwijendra Denpasar.

\section{Hubungan Antara Kontek, Input, Proses dan Produk dengan Pencapaian Kompetensi Pendidikan Agama Hindu di Sekolah Menengah Atas Dwijendra Denpasar}

Hipotesis nol yang diajukan berbunyi terdapat hubungan kontek, input, proses, dan produk dengan pencapaian kompetensi pendidikan agama Hindu di Sekolah Menengah Atas Dwijendra Denpasar. Perumusan indikator yang tepat terkadang tidak mendapat perhatian serius ketika guru menyusun rencana pelaksanaan pembelajaran yang pada akhirnya bermuara pada kegagalan pencapaian kompetensi dasar oleh peserta didik secara individu (Dewi, 2015). Untuk menguji hipotesis ini, dilakukan dengan teknik korelasi ganda dengan bantuan program SPSS for Windows versi 20.0. Berdasarkan hasil analisis korelasi ganda didapat nilai (R) sebesar 0,276, signifikansi sebesar 0,000, $F_{\text {hitung }}$ sebesar 7.311, dan signifikansi $F$ sebesar 0,000. Dengan menggunakan taraf signifikansi 0,05 $(0,000<0,05)$, maka hipotesis nol yang berbunyi terdapat hubungan kontek, input, proses dan produk dengan pencapaian kompetensi pendidikan agama Hindu di Sekolah Menengah Atas Dwijendra Denpasar diterima. Penilaian digunakan sebagai usaha untuk melihat keberhasilan proses belajarmengajar yang ditunjukkan dalam bentuk nilai dan juga digunakan sebagai penilaian terhadap usaha dalam rangka perbaikan suatu penampilan (Rahim, 2001) Dengan demikian, dapat disimpulkan bahwa terdapat hubungan kontek, input, proses dan produk dengan pencapaian kompetensi pendidikan agama Hindu di Sekolah Menengah Atas Dwijendra Denpasar. Sebagian besar orang tua dan guru masih memiliki pandangan baik secara sadar maupun tidak sadar bahwa hasil adalah segalanya, belum kepada bagaimana peserta didik menjalani proses belajarnya melalui berbagai tantangan, keberhasilan dan kegagalan selama proses (Arjanggi, 2012) 


\section{Kesimpulan}

Berdasarkan hasil analisis deskriptif variabel-varibel penelitian dapat dikemukakan kesimpulan sebagai berikut; terdapat hubungan yang signifikan antara variabel kontek dengan pencapaian kompetensi pendidikan agama Hindu di Sekolah Menengah Atas Dwijendra di Denpasar. Hasil ini menunjukkan bahwa makin baik variabel kontek maka akan semakin baik pencapaian kompetensi pendidikan agama Hindu; Terdapat hubungan yang signifikan antara variabel input dengan pencapaian kompetensi pendidikan agama Hindu di Sekolah Menengah Atas Dwijendra di Denpasar. Hasil ini menunjukkan bahwa makin baik variabel input maka akan semakin baik pencapaian kompetensi pendidikan agama Hindu;Terdapat hubungan yang signifikan antara variabel proses dengan pencapaian kompetensi pendidikan agama Hindu di Sekolah Menengah Atas Dwijendra di Denpasar. Hasil ini menunjukkan bahwa makin baik variabel proses maka akan semakin baik pencapaian kompetensi pendidikan agama Hindu; Terdapat hubungan yang signifikan antara variabel produk dengan pencapaian kompetensi pendidikan agama Hindu di Sekolah Menengah Atas Dwijendra di Denpasar. Hasil ini menunjukkan bahwa makin baik variabel produk maka akan semakin baik pencapaian kompetensi pendidikan agama Hindu; Terdapat hubungan yang signifikan antara variabel kontek, input, proses, dan produk dengan pencapaian kompetensi pendidikan agama Hindu di Sekolah Menengah Atas Dwijendra di Denpasar. Hasil ini menunjukkan bahwa makin baik variabel kontek maka akan semakin baik pencapaian kompetensi pendidikan agama Hindu.

\section{Daftar Pustaka}

Abdul Rahim M.Ali. (2001). Penilaian dalam Pendidikan. In Ilmu pendidikan Untuk KPLI.

Arikunto, S. (2019). Dasar-Dasar Evaluasi Pendidikan. In Dasar-dasar Evaluasi Pendidikan (Edisi 3).

Arjanggi, R. (2012). Pendidikan karakter terintegrasi dalam pembelajaran di perguruan tinggi. Prosiding Seminar Nasional Psikologi Islami.

Darojat, W. M. (2015). Model Evaluasi Program Pendidikan. Islamidina.

Dewi, N. (2015). Merancang Pencapaian Kompetensi Dasar Melalui Perumusan Indikator. Jurnal Pendidikan. 
Indonesia, U.-U. R. (2003). Sistem pendidikan nasional. Jakarta: Direktorat Pendidikan Menengah Umum.

Khairani, A. Z. (2016). Mengukur Efikasi Pengajaran Guru Pelatih Universiti Sains Malaysia. Asia Pacific Journal of Educators and Education. https:// doi.org/10.21315/apjee2016.31.2

Kunandar. (2015). Penilaian Autentik (Penilaian Hasil Belajar Pesrta Didik Berdasarkan Kurikulum 2013. In Jurnal Evaluasi Pendidikan. https:// doi.org/10.21009/JEP.022.05

Megawanti, P. (2012). Meretas Permasalahan Pendidikan Indonesia. Jurnal Ilmiah Pendidikan MIPA. https:/ / doi.org/10.30998/ formatif.v2i3.105

Sudarsana, I. K. (2017a). Optimalisasi Pemahaman Ajaran Tri Hita Karana Dalam Meningkatkan Karakter Siswa Sekolah Dasar (Perspektif Psikologi Pendidikan). Prosiding Seminar Nasional Pendidikan Dasar (Senada) 2.

Sudarsana, I. K. (2017b). Peningkatan mutu pendidikan agama hindu melalui efektivitas pola interaksi dalam pembelajaran di sekolah. Prociding SEMAYA 2: Seminar Nasiona Agama \& Budaya. 